\title{
THE FIRST ${ }^{14} \mathrm{C}$ DATING OF MONUMENTS IN EUROPEAN SCYTHIA
}

\author{
GANNA I. ZAITSEVA, ${ }^{1}$ GÖRAN POSSNERT, ${ }^{2}$ ANDREY YU. ALEKSEEV ${ }^{3}$ \\ VALENTIN A. DERGACHEV ${ }^{4}$ and ANATOLY A. SEMENTSOV ${ }^{1}$
}

\begin{abstract}
The first radiocarbon dates for the famous monuments of European Scythia were produced for the Kelermes, Seven Brothers, Solocha and Chertomlyk barrows (burial mounds) by both accelerator mass spectrometry (AMS) and conventional methods. The obtained ${ }^{14} \mathrm{C}$ dates confirmed the traditional archaeological chronology, which was based on the analysis of written data and typological comparisons of Scythian artifacts with similar objects found in the Ancient East and Greece. The ${ }^{14} \mathrm{C}$ dates for the European Scythian monuments are compared with the Asian ones. The ${ }^{14} \mathrm{C}$ chronology of the European Scythian monuments shows chronological synchronisms between the Asiatic and European monuments. The calibrated ages for the investigated barrows generally agree with the archaeological data.
\end{abstract}

\section{INTRODUCTION}

European Scythia was a distinctive culture of the Early Iron Age. It was present in the steppe and forest-steppe zones of European Russia, Ukraine, Northern Caucasus and the Black Sea area during the 1st millennium BC. Scythian culture has left noticeable traces in the history of world culture. The main questions about the European Scythians are the origin of the nomads during this period, the motives for their migrations, and the reason for their sudden disappearance. The answers to these questions can be found in the historical time scale. The first attempts at determining the Scythian chronology began at the end of the 19th century; these initial results were corrected several times. The traditional chronology of European Scythia is based on the analysis of written historical data of the northern Black Sea region, typological comparison of individual Scythian artifacts with similar objects found in the Ancient East and Greece, and the analysis of ceramics and some unique prestigious objects (Alekseev 1996).

In recent studies of the Scythian chronology, there has been a tendency to date the Scythian cultures earlier than previously assumed. The absolute dates for the European Scythian monuments are generally connected with a chronology based on Ancient-Eastern and antique imported objects. The study of independent dates from traditional archaeological methods, such as by radiocarbon dating, has been long overdue. Recently, the ${ }^{14} \mathrm{C}$ method has been successfully applied to establish chronologies for the monuments (burial mounds) of Asian Scythia (Marsadolov 1984, 1987, 1994, 1996; Zaitseva et al. 1996, 1997). The chronology of Asian Scythia was first constructed based on analogies with the European Scythia. Now, however, the ${ }^{14} \mathrm{C}$ dates produced for Asian Scythia allow us to construct an independent time scale. The chronological correlation between European and Asian Scythia shows a "pendulum" effect: the lack of ${ }^{14} \mathrm{C}$ determinations for the European Scythian monuments have moved the chronological comparison in the direction of Asian Scythia.

An important difference between Asian and European Scythian antiquities is that the Asian Scythian monuments contain materials usable both for tree-ring and ${ }^{14} \mathrm{C}$ chronologies. Organic materials from Asian Scythian monuments are very well preserved due to low temperature conditions in the barrows. In contrast, organic material in the European Scythian barrows has practically disappeared. It is almost impossible to find wood for establishing a tree-ring chronology. In addition, the Euro-

\footnotetext{
${ }^{1}$ The Institute of the History of Material Culture, Russian Academy of Sciences, Dvortsovaya nab. 18, St. Petersburg 191186 Russia

${ }^{2}$ The Svedberg Laboratory, Uppsala University, Box 533, S-75121 Uppsala, Sweden

${ }^{3}$ The State Hermitage Museum, Dvortsovaya nab. 34, St. Petersburg 191186 Russia

${ }^{4}$ A. F. Ioffe Physical-Technical Institute, Russian Academy of Sciences, Politechnicheskaya ul. 26, St. Petersburg 194021 Russia
} 
pean Scythian monuments have been excavated during the 19th and the beginning of the 20th centuries, when the ${ }^{14} \mathrm{C}$ method did not yet exist; materials for dating were therefore not collected. Various materials from European Scythian monuments are in the State Hermitage Museum's collections, and most of them can be dated only by accelerator mass spectrometry (AMS). Most of the first ${ }^{14} \mathrm{C}$ dates for European Scythian monuments were produced by AMS. With the availability of ${ }^{14} \mathrm{C}$ dates, we hope that the balance between Asian and European Scythian chronology can be restored. Using the ${ }^{14} \mathrm{C}$ time scale, correlation of the chronologies for Asian and European Scythia is now possible.

\section{RESULTS AND DISCUSSION}

The first ${ }^{14} \mathrm{C}$ dates have been obtained for the best-known European Scythian monument materials present in the collections of the State Hermitage Museum and exhibited in other museums around the world. (See Fig. 1 for a map of the monuments' locations.) The Kelermes monument, located in northwestern Caucasus, was excavated in 1903-1904 and again in 1983-1990. From this monument, we investigated barrow 31. It is dated earlier than other barrows in this group, based on its topographical position (Alekseev 1992). The Seven Brothers barrows, erected in the Taman peninsula on the left bank of the Kuban River, were excavated in 1875-1876. Barrow 4 belongs to the socalled older group compared with barrows 6 and 7 (young group), which were erected later, according to the archaeological materials (Sylanteva 1967; Butjagin 1996).

The Solocha monument is situated on the left bank of the lower Dnieper River. For our research, the richest and most famous tomb of this monument was excavated in 1913. The Chertomlyk monument, situated on the right bank of the lower Dnieper River, was excavated in 1862-1863 and again from 1981-1986. Table 1 shows the results of ${ }^{14} \mathrm{C}$ dating for the samples from these monuments.

The ${ }^{14} \mathrm{C}$ dates were produced by the Svedberg Laboratory of Uppsala University (AMS) and by the Radiocarbon Lab of the Institute of the History of Material Culture (St. Petersburg). Only isolated samples from Kelermes barrow 31 could be dated by the conventional method. They consist of the remains of a wooden barrow construction that is badly preserved (Le-5185), and bone from dogs (Le-5229, Le-5231). These samples were also dated by AMS and the results are similar, within errors (Ua-11671 and Ua-11672). Materials from the other barrows could be dated only by AMS. The representative samples consist of the remains of clothes (leather, fur, wool and textile) and bone fragments from a casket in the Seven Brothers barrows. The sample from Solocha barrow consists of sheep bone from a cauldron.

It is interesting that the samples from the Chertomlyk barrows contain remains from spears used for arrows made from two different types of wood: lime-tree and birch. Most ${ }^{14} \mathrm{C}$ dates agree with the traditional archaeological chronology of the barrow's erection, except for the wool sample from the Chertomlyk barrow and the remains of microorganisms from the vessel of the Seven Brothers barrow. In the latter case, it is difficult to determine the specific features of these microorganisms. One cannot exclude carbon exchange with the environment for these samples during the preservation time. As for the wool samples, the deviation of the age from the traditional picture could be caused by the treatment of wool samples by chemical reagents used to preserve and protect the material. It is impossible now to determine which wool samples have been treated and what organic reagents have been used during the long preservation time $(>100 \mathrm{yr})$. We used the traditional acid-alkali chemical pretreatment for AMS dating of wool (Possnert 1990). It is important when dating samples from a museum collection to know the exact compound used for preservation, in order to select the proper solvents for removing these compounds. This will be the topic of special research in the near future. 


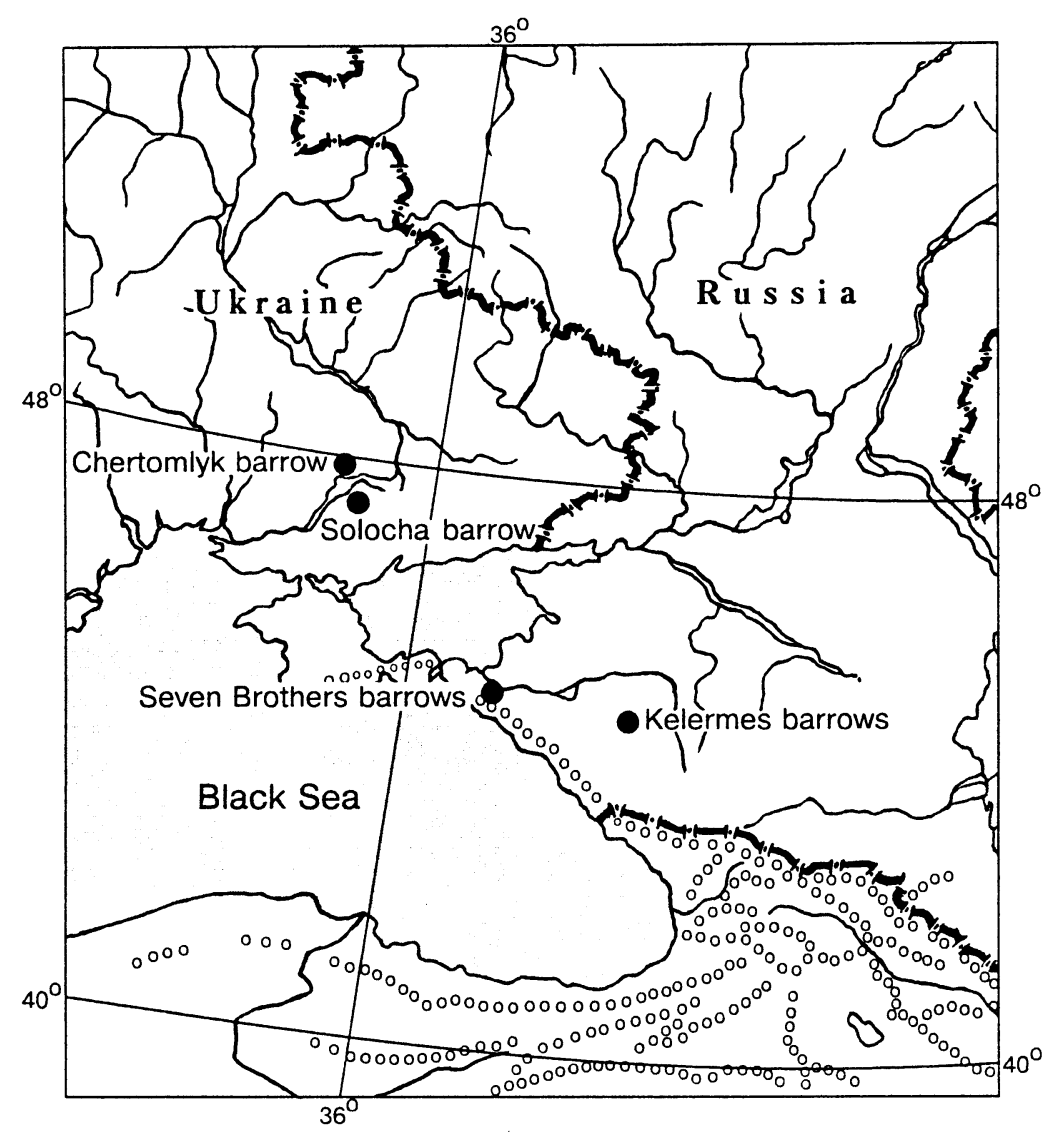

Fig. 1. Location of the European Scythian monuments

The ${ }^{14} \mathrm{C}$ data set is shown in diagram form (Fig. 2), from which we can see the chronological sequence of the barrow's construction: the Kelermes barrow 31, the Seven brothers barrows 4 and 6 , and the Solocha-Chertomlyk barrows, confirming the traditional archaeological chronology.

As mentioned above, the materials from the monuments of European Scythia were used as the basis for the comparison of the chronology of the Asian Scythian monuments. The synchronisms between the key monuments of European and Asian Scythia are established. Thus, the materials from the Arzhan barrow in Tuva were compared with materials from the Kelermes barrows, but the chronology of the Arzhan barrow is considered to be somewhat older than the Kelermes barrow. The materials from the group of Pazyryk barrows in the Gornyi Altai region show resemblance with materials from the Seven Brothers barrows (Marsadolov 1987). For these monuments of Asian Scythia, the series of ${ }^{14} \mathrm{C}$ dates were produced in the $1980 \mathrm{~s}$ and became the basis for the chronology. They were previously used as a reference for the chronology of the European Scythia monuments because of the lack of ${ }^{14} \mathrm{C}$ dates. Now, however, we have the opportunity to compare the chronological positioning of both European and Asian Scythia on the ${ }^{14} \mathrm{C}$ time scale. The ${ }^{14} \mathrm{C}$ dates for the Arzhan and Pazyryk barrows (Marsadolov 1994; Zaitseva et al. 1996, 1997) are shown in Figure 3 in diagram form. Comparing Figure 2 with Figure 3, we can see that the chronological synchronism between Asian and European Scythian monuments mentioned above is corroborated. 
TABLE $1 .{ }^{14} \mathrm{C}$ Dates for the Famous Barrows of the European Scythian Culture

\begin{tabular}{|c|c|c|c|c|c|c|c|}
\hline \multirow[b]{2}{*}{ No. } & \multirow[b]{2}{*}{ Lab code } & \multirow{2}{*}{$\begin{array}{l}{ }^{14} \mathrm{C} \text { age } \\
\text { (yr BP) }\end{array}$} & \multirow{2}{*}{$\begin{array}{l}8^{13} \mathrm{C} \\
(\% 0)\end{array}$} & \multirow{2}{*}{$\begin{array}{c}\text { Barrow } \\
\text { no. }\end{array}$} & \multirow[b]{2}{*}{ Material } & \multicolumn{2}{|c|}{$\begin{array}{l}\text { Calibrated age } \\
\text { (BC unless noted) }\end{array}$} \\
\hline & & & & & & $1 \sigma$ & $2 \sigma$ \\
\hline \multicolumn{8}{|c|}{ Kelermes barrows, Russia (the northern Caucasus) } \\
\hline 1 & Ua-11671 & $2555 \pm 50$ & -17.72 & 31 & Bone (dog's jaw) & $\begin{array}{l}800-760 \\
678-656\end{array}$ & $812-516$ \\
\hline 2 & Ua-11672 & $2520 \pm 60$ & -27.29 & 31 & Wood & $\begin{array}{l}636-550 \\
792-752\end{array}$ & $800-480$ \\
\hline \multirow[t]{3}{*}{3} & Le-5185 & $2610 \pm 60$ & -27.29 & 31 & Wood & $\begin{array}{l}698-530 \\
836-762\end{array}$ & $\begin{array}{l}452-414 \\
902-752\end{array}$ \\
\hline & & & & & & $672-666$ & 728-714 \\
\hline & & & & & & $630-594$ & $704-530$ \\
\hline \multirow[t]{2}{*}{4} & Le-5229 & $2540 \pm 40$ & -17.72 & 31 & Bone (dog) & $\begin{array}{l}578-556 \\
794-760\end{array}$ & $802-750$ \\
\hline & & & & & & $678-658$ & $734-526$ \\
\hline 5 & Le-5231 & $2690 \pm 150$ & -17.72 & 31 & Bone (dog) & $\begin{array}{l}634-552 \\
1040-760 \\
680-540\end{array}$ & $1200-410$ \\
\hline \multicolumn{8}{|c|}{ The group of Seven brothers barrows, Russia (the Kuban River basin) } \\
\hline \multirow[t]{2}{*}{6} & Ua-11664 & $2440 \pm 40$ & -20.91 & 4 & Leather from clothes & $752-698$ & $762-628$ \\
\hline & & & & & & $532-410$ & $598-572$ \\
\hline 7 & Ua-11668 & $2530 \pm 40$ & -25.37 & 4 & Textile from clothes & $\begin{array}{l}790-760 \\
680-654\end{array}$ & $\begin{array}{l}562-402 \\
800-744 \\
742-522\end{array}$ \\
\hline \multirow[t]{2}{*}{8} & Ua-11669 & $2255 \pm 35$ & -19.06 & 4 & Wool from clothes & $\begin{array}{l}640-548 \\
382-356\end{array}$ & $390-342$ \\
\hline & & & & & & $294-242$ & $326-200$ \\
\hline \multirow[t]{2}{*}{9} & Ua-11665 & $2305 \pm 60$ & -22.55 & 6 & Bone from casket & $\begin{array}{l}234-208 \\
404-351\end{array}$ & $516-434$ \\
\hline & & & & & & $296-240$ & $424-192$ \\
\hline \multirow[t]{2}{*}{10} & Ua-11667 & $2235 \pm 40$ & -20.69 & 6 & Fur from clothes & $\begin{array}{l}236-208 \\
368-350\end{array}$ & 382-196 \\
\hline & & & & & & $312-272$ & \\
\hline 11 & Ua-11670 & $2060 \pm 40$ & -21.88 & 7 & Wool from clothes & $\begin{array}{l}268-206 \\
106-2 \mathrm{AD}\end{array}$ & $174-21 \mathrm{AD}$ \\
\hline 12 & Ua-11666 & $2710 \pm 40^{*}$ & -21.52 & 4 & $\begin{array}{l}\text { Microorganisms } \\
\text { from vessel }\end{array}$ & $\begin{array}{l}898-872 \\
854-814\end{array}$ & $\begin{array}{l}42-56 \mathrm{AD} \\
912-806\end{array}$ \\
\hline \multicolumn{8}{|c|}{ Solocha barrow (Ukraine) $†$} \\
\hline \multirow[t]{2}{*}{13} & Ua-11673 & $2265 \pm 50$ & -20.12 & & Sheep bone & $388-354$ & $396-334$ \\
\hline & & & & & & $\begin{array}{l}296-240 \\
238-208\end{array}$ & $332-200$ \\
\hline \multicolumn{8}{|c|}{ Chertomlyk barrow (Ukraine) $\ddagger$} \\
\hline \multirow[t]{2}{*}{14} & Ua-11674 & $2130 \pm 50$ & -24.05 & & $\begin{array}{l}\text { Spear for arrows } \\
\text { from lime-tree }\end{array}$ & $194-62$ & $\begin{array}{l}358-288 \\
252-224\end{array}$ \\
\hline & & & & & & & $\begin{array}{l}212-30 \\
22-4\end{array}$ \\
\hline 15 & Ua-11675 & $2150 \pm 50$ & -24.32 & & $\begin{array}{l}\text { Spear for arrows } \\
\text { from birch }\end{array}$ & $\begin{array}{l}348-326 \\
204-94\end{array}$ & $\begin{array}{l}362-282 \\
258-44\end{array}$ \\
\hline 16 & Ua-11676 & $1420 \pm 40 \S$ & -22.69 & & Wool from clothes & $\begin{array}{l}82-66 \\
616-660 \text { AD }\end{array}$ & $\begin{array}{l}558-576 \mathrm{AD} \\
592-674 \mathrm{AD}\end{array}$ \\
\hline
\end{tabular}

"Some uncertainty aboud the dated material

† Materials from the 1913 excavation

$¥$ Materials from the 1863 excavation

§This sample was chemically treated for moth protection. 


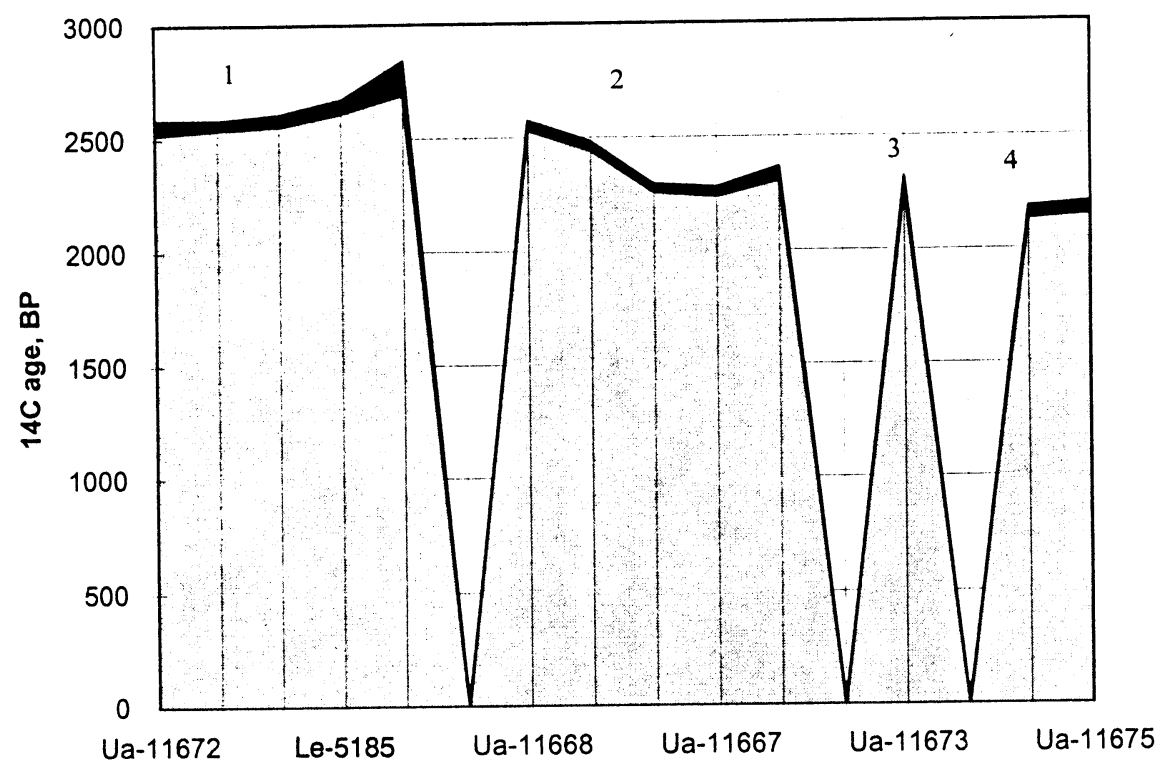

Fig. 2. Diagram of ${ }^{14} \mathrm{C}$ dates for the European Scythian monuments. 1. Kelermes barrow; 2. Seven Brothers barrows; 3. Solocha barrow; 4 . Chertomlyk barrow.

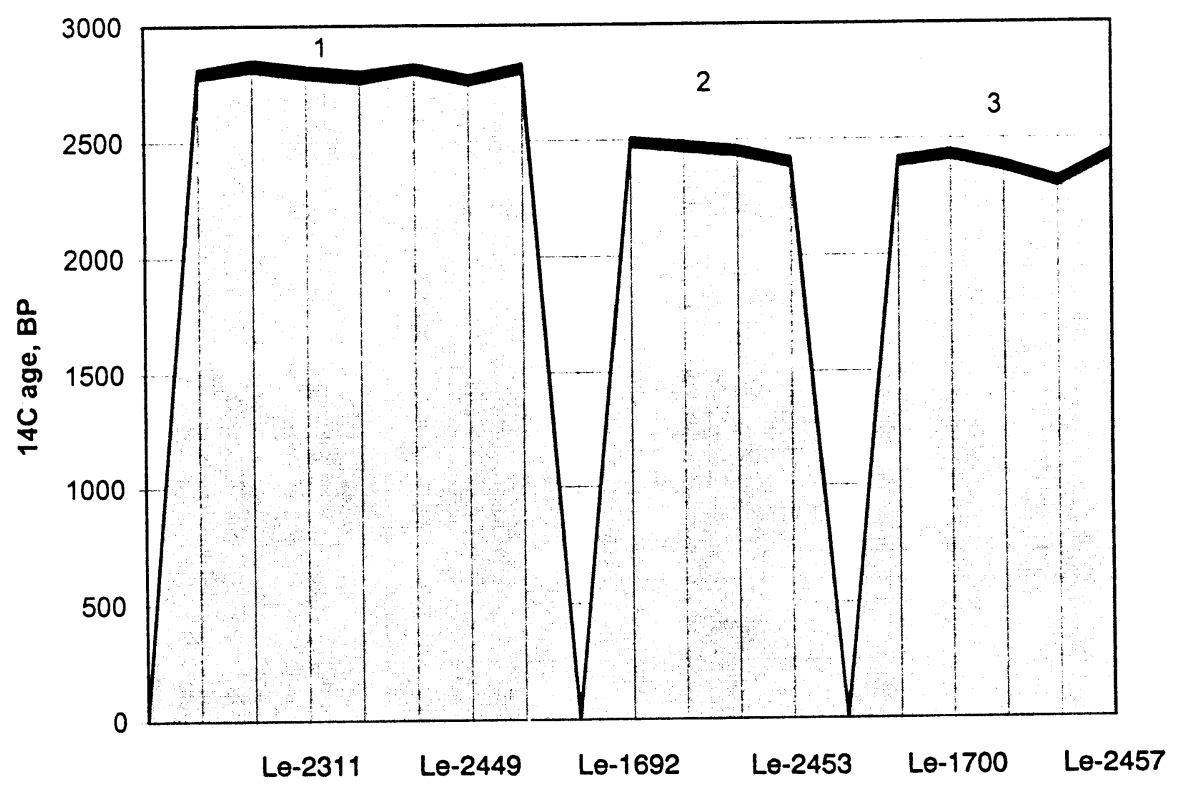

Fig. 3. Diagram of ${ }^{14} \mathrm{C}$ dates for the Asian Scythian key monuments (Marsadolov 1994; Zaitseva et al. 1997). 1. Arzhan barrow; 2. Pazyryk-2 barrow; 3. Pazyryk-5 barrow. 


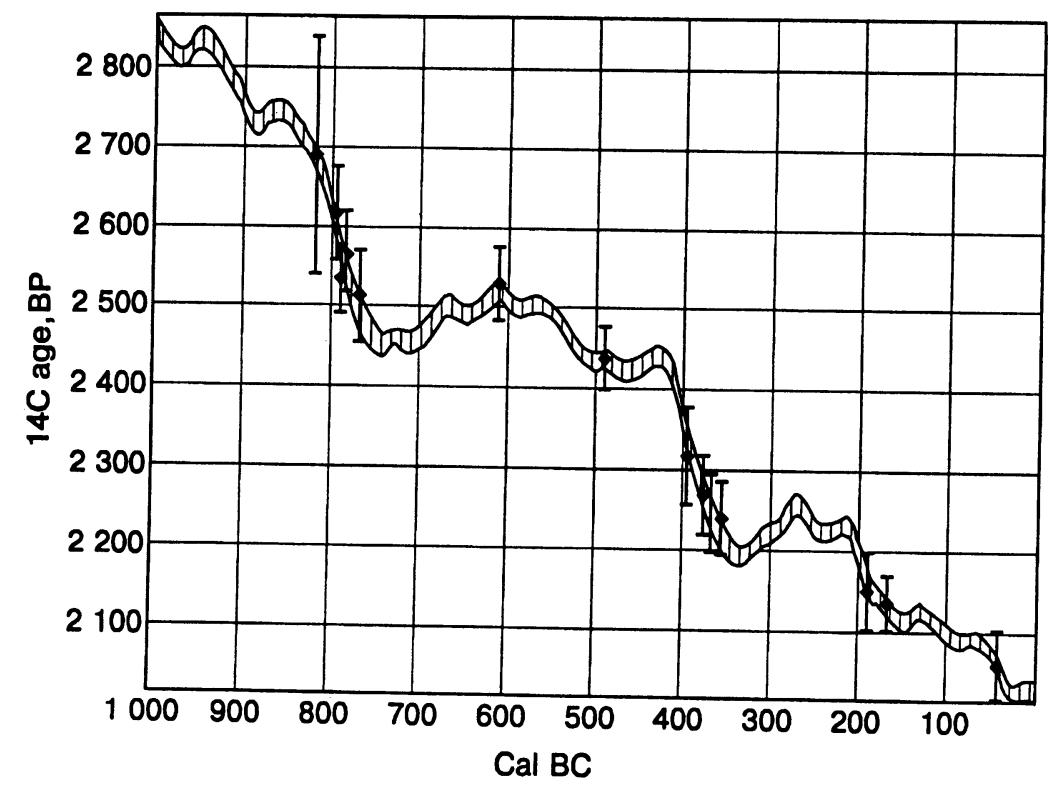

Fig. 4. Part of the calibration curve by Stuiver and Pearson (1986) for the range of ${ }^{14} \mathrm{C}$ dates produced for the monuments of European Scythia

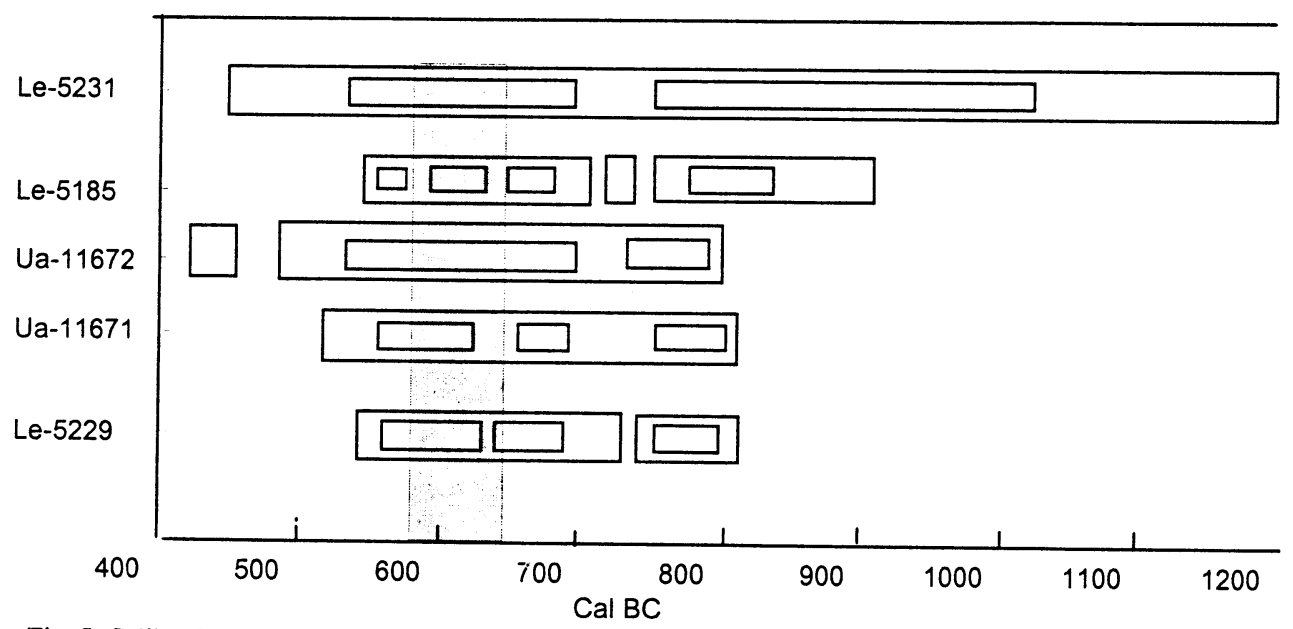

Fig. 5. Calibration calendar intervals ( 1 and $2 \sigma)$ of ${ }^{14} \mathrm{C}$ dates for Kelermes barrow 31

The determination of the European Scythia chronology is very important. Considerable progress in European Scythian chronology has been achieved, compared with Asian Scythian chronology, based on ceramic epigraphy (Brashinsky 1965). Calendar year intervals spanning ca. $25 \mathrm{yr}$ are currently under discussion. Unfortunately, in "radiocarbon time", the Scythian period coincides with $2500 \mathrm{BP}$ plateau in the calibration curve. Figure 4 shows the relevant part of the curve (Stuiver and Pearson 1986) and the position of ${ }^{14} \mathrm{C}$ dates for the samples investigated. From this figure, one can see that there are several calendar time intervals for almost all ${ }^{14} \mathrm{C}$ dates obtained. The lack of tree-ring material in the European Scythian monuments does not allow us to improve the calibration (by wiggle- 
matching, for example) but it is possible to choose a reliable calendar time interval using the available archaeological evidence. The probable calendar time intervals (for 1 and $2 \sigma$ ) are shown in Figure 5 for the ${ }^{14} \mathrm{C}$ dates of the Kelermes barrow. The calendar time interval for this barrow, according to the analyses of art objects produced by Middle-Eastern masters, is 650-580 BC (Alekseev 1992, 1996). This time interval is more acceptable than all other possible intervals (Fig. 5). In this case, we can say that the archaeological data are confirmed by ${ }^{14} \mathrm{C}$ dates.

Quite a different picture exists for the Seven Brothers barrows. The calendar time intervals for these barrows are shown in Figure 6(A). Here one can select two barrow groups according to the chronology: barrow 4 belonging to the old group, and barrow 6 erected some time later. These facts are confirmed by archaeological data (Sylanteva 1967; Butjagin 1996). Barrow 4 of this monument is dated from $460-425 \mathrm{BC}$, based on the analyses of imported materials (most of which are horse bridles) (Sylanteva 1967; Butjagin 1996). This is confirmed by one ${ }^{14} \mathrm{C}$ date (Ua-11664). Two other ${ }^{14} \mathrm{C}$ dates are older (Ua-11668) and later (Ua-11668), respectively. Because this barrow yields only isolated ${ }^{14} \mathrm{C}$ dates, it is difficult to explain the cause of these deviations. According to the archaeological data, barrow 6 was erected in 400-380 BC (Alekseev 1992). This date agrees with the calibration interval of the ${ }^{14} \mathrm{C}$ dates for this barrow. The calibration interval for the ${ }^{14} \mathrm{C}$ date of the Solocha barrow falls into the interval $400-375 \mathrm{BC}$, as suggested by many archaeologists (Fig. 6B). For the Chertomlyk barrow, the interval $348-325 \mathrm{BC}(1 \sigma)$ (Fig. 6C) is very close to the archaeological dates $(350-325 \mathrm{BC})$ (Alekseev 1992). Based on our investigations, we declare the terminus post quem for Solocha and Chertomlyk barrows as 396 and $362 \mathrm{BC}(2 \sigma)$, respectively.

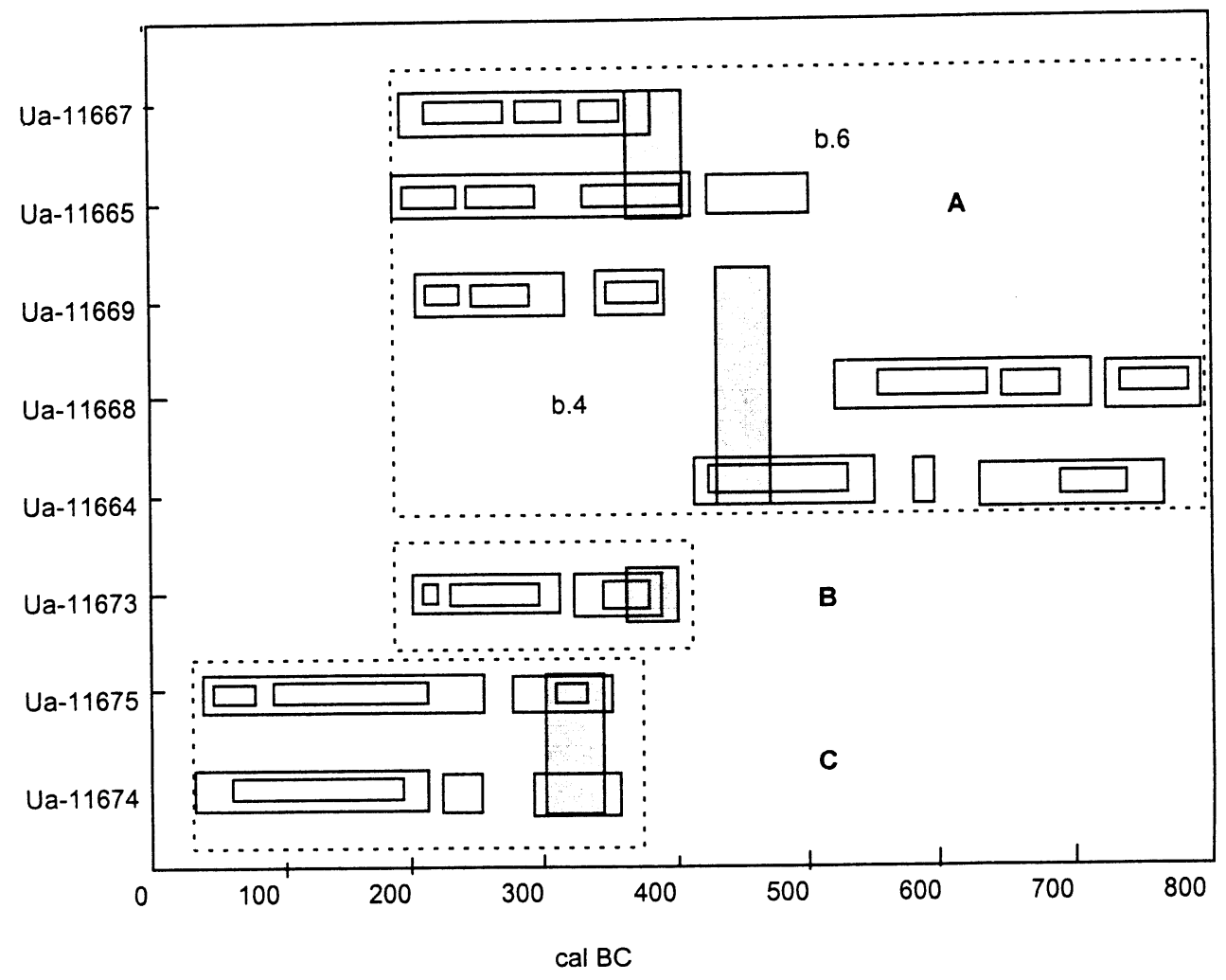

Fig. 6. The calibration calendar intervals $(1$ and $2 \sigma)$ of ${ }^{14} \mathrm{C}$ dates for the Seven Brothers barrows (A), Solocha barrow (B) and Chertomlyk barrow (C) 


\section{ConClusion}

The first ${ }^{14} \mathrm{C}$ dates produced for the monuments of European Scythia confirm the traditional archaeological chronology, both concerning its sequence and the calendar time intervals of their constructions. The ${ }^{14} \mathrm{C}$ dates of the monuments of European Scythia make it possible to synchronize the chronology of Asian and European Scythia. In general, the calibrated time intervals of ${ }^{14} \mathrm{C}$ dates agree with those accepted by archaeologists.

\section{ACKNOWLEDGMENTS}

We are grateful to L. K. Galanina (Department of the East Europe and Siberia) and to E. V. Vlasova (Department of the Art and Culture Antiquity) from the State Hermitage Museum for providing different samples for this research.

\section{REFERENCES}

Alekseev, A. Yu. 1992 Scythian Chronicle (Scyths in 74 century BC: historical-archaeological review). St. Petersburg, Goskomstat: 210 p. (in Russian). 1996 (ms.) Chronography of European Scythian 74 century BC. PhD. dissertation. The Institute of the History of Material Culture of Russian Academy of Sciences. St. Petersburg: 50 p. (in Russian).

Brashinsky, I. B. 1965 The New Data on the Dating of the Scythian Nobility's Barrows in the North Black Sea Region. Eirene, Praha: 89-110 (in Russian).

Butjagin, A. M. 1996 The chronology of Seven Brothers barrows and the history of Sindica. In Barrows: Historical and Cultural Investigations and Reconstructions. Reports of Scientific Conference in St. Petersburg. St. Petersburg University: 44-45 (in Russian).

Marsadolov, L. S. 1984 About the sequence of the construction of fifth great Pazyryk barrows in Altai. Archaeological Journal of the State Hermitage Museum 25: 90-98 (in Russian).

1987 The chronological correlation between Pazyryk and Seven Brothers Barrow. Archaeological Journal of the State Hermitage Museum 28: 30-37 (in Russian).

1996 History and the Results of the Research of Archaeological Monuments in Sayan-Altai of the 8th4th Cent. BC (from the Beginning up to the 80th). St. Petersburg, Vichi. (in Russian).

Marsadolov, L. S., Zaitseva, G. I., Lebedeva, L. M. 1994 The correlation of tree-ring chronology and radiocarbon data for the great barrows of Sayan-Altai. In Alexeev, A., Bokovenko, N. A. and Marsadolov, L. S., eds., Elite Barrows of Eurasian Steppe in Scythian and Sarmathian Epoch. St. Petersburg: 141-157 (in Russian).

Possnert, G. 1990 Radiocarbon dating by the accelerator technique. Norwegian Archaeological Review 23(12): 30-37.

Sylanteva, L. F. 1967 The Seven Brothers barrows and their significance for the culture of Sindis. In Piotrovskiy, B., ed., Reports of the Scientific Session of the State Hermitage Museum. Leningrad: 46-48 (in Russian).

Stuiver, M. and Pearson. G. W. 1986 High-precision calibration of the radiocarbon time scale, AD 1950-500 BC. In Stuiver, M. and Kra, R., eds., Calibration Issue. Radiocarbon 28(2B): 805-838.

Zaitseva, G. I., Marsadolov, L. S., Sementsov, A. A., Vasiliev, S. S., Dergachev, V. A. and Lebedeva L. M. 1996 Using the mathematical-statistical methods for the correlation of dendro- and radiocarbon data (on the materials of the elite barrows of Sayan-Altai). In Zaitseva, G., Dergachev, V. and Masson, V., eds., Radiocarbon and Archaeology 1. St. Petersburg. Tesa: 3339 (in Russian).

1997 The mathematical-statistical method for the correlation of dendro- and radiocarbon data (on the materials of the elite barrows of Sayan-Altai). In Jungner, H. and Lavento, M., eds., Proceedings of the 7th Nordic Conference on the Application of Scientific Methods in Archaeology, Savonlinna, Finland, 1996. Suomen Muinaismuistoyhdistys Finska Fornminnesföreningen 11: 23-32. 